\title{
Clinical Potential of Statins in Prostate Cancer Radiation Therapy
}

\author{
JACK HUTCHINSON and LAURE MARIGNOL \\ Applied Radiation Therapy Trinity, Discipline of Radiation Therapy, Trinity College Dublin, Dublin, Ireland
}

\begin{abstract}
Background/Aim: Statins are cholesterol- lowering drugs that have been shown to possess anti-tumour properties. Observational studies have shown that 3-hydroxy-3methlyglutaryl coenzyme A reductase inhibitor (statin) use may be associated with reduced prostate cancer risk. Preclinical studies suggest that statins possess anticancer and radiosensitising properties. This review aims to determine the impact of statin use in the efficacy of radiation therapy and the therapeutic window in prostate cancer. Materials and Methods: The scientific databases PubMed, Science Direct, EMBASE, Cochrane Collaboration, and Google Scholar were searched for articles identifying statin use in histologically confirmed prostate cancer treated with external beam radiation therapy. Results: Improvement was observed in freedom from biochemical failure (91\% vs. $79 \%)$, relapse free survival $(72 \%$ vs. 69\%), distant metastasis free survival (96\% vs. 94\%), and prostate-specific antigen (PSA) relapse free survival (89\% vs. $83 \%)$ with statin use, however this did not translate into an overall survival benefit for patients. Conflicting data concerning clinical outcomes reduce the integrity of these findings. The literature supports the radiosensitising properties of statins and their potential antitumor effects in prostate cancer. Conclusion: Statin use in prostate cancer presents many obstacles yet to be overcome, which warrant attention prior to the routine implementation of statins in treatment regimes. However, there is evidence to support their beneficial use.
\end{abstract}

This article is freely accessible online.

Correspondence to: Dr Laure Marignol, Applied Radiation Therapy Trinity, Discipline of Radiation Therapy, Trinity Centre for Health Sciences, St James's Hospital, Dublin 8, Ireland. Tel: +353 18963255, e-mail: marignl@tcd.ie

Key Words: Statins, prostate cancer, radiotherapy, review.
The management of prostate cancer is a significant healthcare challenge. Many treatment options exist (1-3), with radiation therapy playing a prominent role. However, the morbidity and cost of treatment are not trivial $(4,5)$. Although risk classification schemes (6) and nomograms (7) attempt to identify men most likely to benefit from treatment, it remains difficult to balance the risks of disease progression against competing risks of mortality (8). This has resulted in controversy over prostate-specific antigen (PSA) screening $(9,10)$ and possible overtreatment leading to a decreased quality of life $(5,11)$. Therefore, it is of great interest to conduct research into cancer prevention strategies (12), identification of men who will benefit most from treatment, and effective therapies that limit treatment-related morbidity of prostate cancer.

Statins or 3-hydroxyl-3-methylglutaryl-coenzyme A (HMG$\mathrm{CoA}$ ) reductase inhibitors are widely used medications for hypercholesterolaemia. The demographics of prostate cancer and hypercholesterolaemia overlap. The prevalence of statin use in this older men population is high-approximately 24 million Americans in 2003-2004 (13). Thus, many prostate cancer patients are likely to have already been prescribed statins at the time of their cancer diagnosis and treatment.

Initial interest in the use of statins in prostate cancer stemmed from epidemiological studies that investigated their chemopreventive properties. Two large case-control series reported a $50 \%-65 \%$ reduction in overall prostate cancer risk among statin users compared with non-users $(14,15)$. In the Health Professionals Follow-up Study (16), 34,989 U.S. male health professionals were followed from 1990 to 2002. Statin users were noted to have a $49 \%$ reduction in the risk of developing advanced prostate cancer (relative risk [RR] 0.51; $95 \%$ confidence interval $[\mathrm{CI}], 0.30-0.86)$ and a $61 \%$ reduction in metastatic or fatal prostate cancer $(\mathrm{RR}=0.39$; $95 \% \mathrm{CI}=0.19$ 0.77). Similar risk reductions for advanced prostate cancer were presented in the Cancer Prevention Study II Nutrition Cohort and the California Men's Health Cohort Study $(17,18)$. 
Table I. Summary of clinical studies investigating the impact of statins use in radiotherapy prostate cancer patients.

\begin{tabular}{|c|c|c|c|}
\hline Author & Title & Disease, \# of patients & Major End-points \\
\hline Nielsen et al. (25) & $\begin{array}{l}\text { Statin use and reduced } \\
\text { cancer-related mortality. }\end{array}$ & Prostate cancer, 18,721 & $\begin{array}{l}\text { Statin use in patients with prostate cancer is associated } \\
\text { with reduced cancer-related mortality. } \\
\text { Suggest a need for trials of statins in patients with cancer. }\end{array}$ \\
\hline Platz et al. (16) & $\begin{array}{l}\text { Statin drugs and risk of } \\
\text { advanced prostate cancer. }\end{array}$ & $\begin{array}{l}\text { Prostate cancer, } 34,989 \\
\text { US male health } \\
\text { professionals }\end{array}$ & $\begin{array}{l}\text { In this cohort of male health professionals, use of statin drugs } \\
\text { was not associated with risk of prostate cancer overall but } \\
\text { was associated with a reduced risk of advanced } \\
\text { (especially metastatic or fatal) prostate cancer. }\end{array}$ \\
\hline Jacobs et al. (17) & $\begin{array}{l}\text { Cholesterol-lowering } \\
\text { drugs and advanced prostate } \\
\text { cancer incidence in a } \\
\text { large U.S. cohort. }\end{array}$ & $\begin{array}{l}\text { Prostate cancer, } \\
55,454 \text { men }\end{array}$ & $\begin{array}{l}\text { Long-term statin use is associated with reduced } \\
\text { risk of advanced prostate cancer. }\end{array}$ \\
\hline Kollmeier et al. (37) & $\begin{array}{l}\text { Improved Biochemical } \\
\text { Outcomes With Statin } \\
\text { Use in Patients With } \\
\text { High-Risk Localized } \\
\text { Prostate Cancer Treated } \\
\text { With Radiotherapy }\end{array}$ & $\begin{array}{c}\text { Prostate cancer, } \\
1711\end{array}$ & $\begin{array}{l}\text { Statin use during high-dose radiotherapy for clinically } \\
\text { localized prostate cancer was associated with a significant } \\
\text { improvement in PRFS in high-risk patients. } \\
\text { These data suggest that statins have anticancer activity and } \\
\text { possibly provide radiosensitisation when used in conjunction } \\
\text { with radiotherapy in the treatment of prostate cancer. }\end{array}$ \\
\hline Murtola et al. (34) & $\begin{array}{l}\text { Cholesterol-lowering } \\
\text { drugs and prostate } \\
\text { cancer risk: } \\
\text { a population-based } \\
\text { case-control study }\end{array}$ & $\begin{array}{l}\text { Prostate cancer, } \\
24,723\end{array}$ & $\begin{array}{c}\text { No evidence for reduced overall prostate cancer risk } \\
\text { among users of cholesterol-lowering drugs, } \\
\text { whereas the risk of advanced cancer was } \\
\text { decreased among statin users. }\end{array}$ \\
\hline Park et al. (44) & $\begin{array}{l}\text { Statins and prostate } \\
\text { cancer recurrence } \\
\text { following radical } \\
\text { prostatectomy or } \\
\text { radiotherapy: a } \\
\text { systematic review } \\
\text { and meta-analysis. }\end{array}$ & Prostate cancer & $\begin{array}{l}\text { Meta-analysis suggests a potentially beneficial effect of } \\
\text { statins on prostate cancer patients treated with radiotherapy } \\
\text { but not among radical prostatectomy patients. } \\
\text { Although limited by the lack of randomized data, these } \\
\text { results suggest that primary treatment modality should be } \\
\text { considered in future studies examining associations } \\
\text { between statins and oncologic outcomes. }\end{array}$ \\
\hline Gutt et al. (36) & $\begin{array}{l}\text { Statin use and risk } \\
\text { of prostate cancer } \\
\text { recurrence in men } \\
\text { treated with } \\
\text { radiation therapy. }\end{array}$ & $\begin{array}{l}\text { Prostate cancer, } \\
\quad 691\end{array}$ & $\begin{array}{l}\text { Statin use was associated with a significant improvement } \\
\text { in FFBF, FFADT, and RFS in this cohort of men treated } \\
\text { with radiotherapy for prostate cancer. The favorable } \\
\text { effect of statins may be mediated by direct effect or via } \\
\text { the LDL-cholesterol lowering effect of these medications. }\end{array}$ \\
\hline Haukka et al. (42) & $\begin{array}{l}\text { Incidence of cancer } \\
\text { and statin usage-- } \\
\text { record linkage study. }\end{array}$ & $\begin{array}{l}\text { Prostate cancer, } \\
\quad 472,481\end{array}$ & $\begin{array}{l}\text { In conclusion, this study adds large-scale, population-based } \\
\text { results about the association between statin utilization and } \\
\text { the incidence of cancer. We found neither beneficial nor } \\
\text { harmful associations between the usage of statins and cancer. }\end{array}$ \\
\hline Sun et al. (43) & $\begin{array}{l}\text { Statin Use Reduces } \\
\text { Prostate Cancer } \\
\text { All-Cause Mortality: } \\
\text { A Nationwide }\end{array}$ & $\begin{array}{l}\text { Prostate cancer, } \\
5179\end{array}$ & $\begin{array}{l}\text { The results of this population-based cohort study suggests } \\
\text { that using statins reduces all-cause mortality among prostate } \\
\text { cancer patients, and a dose-response relationship may exist. }\end{array}$ \\
\hline
\end{tabular}

Caon et al. (45)

Population-Based Cohort Study.

Does Statin or

ASA Affect Survival

When Prostate

Cancer Is Treated with External

Beam Radiation Therapy?

Boudreau et al. (46) Statin use and prostate cancer risk in a large populationbased setting.

Statin use did not impact PCSS on multivariate competing risk analysis. Survival was impacted by increased comorbidity as well as statin use.

3851 , of which $34 \%$ took statins (23\% statins alone, and $11 \%$ statins and ASA)

Prostate cancer, Among 83,372 men studied, median follow-up time was 5.7 years and 2,532 prostate cancer cases were identified. About $14.4 \%$ used statins over the study period. 
Table I. Continued

\begin{tabular}{|c|c|c|c|}
\hline Author & Title & Disease, \# of patients & Major End-points \\
\hline Soto et al. (35) & $\begin{array}{l}\text { No effect of statins } \\
\text { on biochemical } \\
\text { outcomes after } \\
\text { radiotherapy for } \\
\text { localized } \\
\text { prostate cancer. }\end{array}$ & $\begin{array}{l}\text { Prostate cancer, } \\
23 \% \text { of } 968 \\
\text { patients took statins }\end{array}$ & $\begin{array}{c}\text { Statin use did not affect PFS after adjusting for differences } \\
\text { in treatment year and multiple prognostic factors. } \\
\text { However, T stage, baseline PSA level, and Gleason } \\
\text { score were critical determinants of PSA failure. }\end{array}$ \\
\hline Shannon et al. (14) & $\begin{array}{l}\text { Statins and } \\
\text { prostate cancer } \\
\text { risk: a case- } \\
\text { control study }\end{array}$ & $\begin{array}{l}\text { Prostate cancer, } \\
\text { Thirty-six percent } \\
\text { of cases and } 49 \text { percent } \\
\text { of controls had a } \\
\text { record of any statin use. }\end{array}$ & $\begin{array}{l}\text { The results of this case-control study suggest that statins } \\
\text { may reduce the risk of total prostate cancer and, } \\
\text { specifically, more aggressive prostate cancer. }\end{array}$ \\
\hline Graaf et al. (15) & $\begin{array}{l}\text { The risk of cancer } \\
\text { in users of statins. }\end{array}$ & $\begin{array}{l}\text { Prostate cancer, } \\
3129\end{array}$ & $\begin{array}{c}\text { This observational study suggests that statins may have } \\
\text { a protective effect against cancer. }\end{array}$ \\
\hline Flick et al. (18) & $\begin{array}{l}\text { Statin use and } \\
\text { risk of prostate } \\
\text { cancer in the } \\
\text { California Men's } \\
\text { Health Study cohort. }\end{array}$ & $\begin{array}{l}\text { Prostate cancer, } \\
\quad 69,047\end{array}$ & $\begin{array}{l}\text { Findings suggest that long-term statin use might be associated } \\
\text { with a reduced risk of prostate cancer but perhaps only } \\
\text { among regular nonsteroidal anti-inflammatory drug users. }\end{array}$ \\
\hline
\end{tabular}

PRFS, Prostate cancer recurrence-free survival; PCSS, prostate cancer-specific survival; PFS, progression-free survival; FFBF, freedom from biochemical failure; FFADT, freedom from androgen deprivation therapy; RFS, recurrence-free survival; PSA, prostate-specific antigen.

Statins possess anti-inflammatory, immunomodulatory, anti-oxidant and growth inhibitory properties (19). By inhibiting cholesterol synthesis, statins also inhibit the production of farnesyl pyrophosphate and geranylgeranyl pyrophosphate, two biochemical products essential for cell growth and proliferation $(20,21)$. Inhibition of 3-hydroxyl3-methylglutaryl CoA reductase by statins interferes with the rate-limiting step in the mevalonate pathway (22), leading to reduced levels of mevalonate and its downstream products, many of which play a critical role in cellular functions such as membrane integrity, protein synthesis, cell cycle progression and cell signalling (23).

These properties have the potential to extend the indication of statins to the improved management of cancer patients. Statins have been proposed to inhibit carcinogenesis and impact cancer outcomes (24). One large, population-based study demonstrated an association between statin use and reduced cancer-specific mortality across multiple cancer subtypes (25), including prostate cancer. As a result, the impact of statins on prostate cancer incidence, aggressiveness and outcomes is potentially huge. Preclinical studies suggest that statins might exert a chemopreventive role against prostate cancer by inhibiting proliferation and inducing apoptosis in prostate cancer cells, and also by inhibiting angiogenesis, inflammation and metastasis (24). By targeting cholesterol synthesis, statins may also decrease the ability of prostate cancer tissue to synthesise testosterone de novo and thus, impede progression to metastatic disease $(26,27)$. In combination with radiation, statins have the potential to improve clinical outcomes via their radiosensitising properties, however, the available clinical data is conflicting (16, 28-34). This review proposes to evaluate the clinical potential of statins to improve clinical outcomes of radiotherapy prostate cancer patients.

\section{Materials and Methods}

Search strategy for identification of studies. The scientific databases PubMed, Science Direct, EMBASE, Cochrane Collaboration, and Google Scholar were searched for trials and studies including metaanalysis and systematic reviews. Search terms relating to statins, HMG-CoA reductase inhibitors, prostate cancer and radiotherapy were used alone or in combination. Only studies written in English published in the year 1995 or thereafter were included. Reference lists were hand searched to identify further trials. The last literature search was performed on 01/07/2017.

Type of studies. Published trials and studies on the treatment of prostate cancer with the use of statins were included. Studies were limited to those evaluating the effect of statins on prostate cancer patients undergoing radiation therapy as a primary treatment modality.

Type of participants. All participants were men with a diagnosis of prostate cancer confirmed with histology/cytology treated with external beam radiation therapy (EBRT) either at initial diagnosis or upon recurrence. Treatment may have been received alone or in combination with surgical and/or chemotherapeutic interventions 
Outcome measures. Primarily studies identifying the antitumor effects of statins in a prostate cancer setting were selected, in order to determine whether there are any differences in clinical outcomes for statin users versus non-statin users undergoing EBRT. The identified clinical outcomes included overall survival (OS), prostate cancer-specific survival (PCSS), freedom from biochemical failure (FFBF), relapse-free survival (RFS), and distant metastasis-free survival (DMFS). Other factors considered were the effects of statin on the risk of developing prostate cancer, and the risk of cancer progression into more advanced disease.

Statistical analysis. The included studies applied a number of methods in their statistical analysis. The Kaplan-Meier method was used by authors to compute progression free survival, PSA RFS and actuarial survival curves. For further analysis of prognostic factors, authors applied the Cox proportional hazards model to examine the impact of demographical, clinical, and statin related variables. Univariate and multivariate analysis was performed across certain studies. T-tests were used to compare variables and distributions between participant groups of individual studies. $p$-Values of $<0.05$ were considered significant across the studies.

\section{Results and Discussion}

Statins prescription in radiotherapy prostate cancer patients. Soto et al. examined the role of statin use during EBRT and reported a significant improvement in 5-year progressionfree survival $(70 \%$ vs. $59 \% ; p=0.03)$ in favor of statin users $v s$. non-users (35). However, when adjustments were made for treatment year and risk group, this benefit was no longer noted. It is unclear whether longer follow-up is needed in this cohort to establish a benefit, as there was a relatively short median follow-up of 3.1 years for statin users in that series (Table I).

Analysis of the entire cohort $(n=691)$ in the Gutt et al. (36) paper revealed a freedom from biochemical failure (FFBF) of $83 \%$ and a recurrence free survival (RFS) of $73 \%$ at 4 years. By risk category, 4-year FFBF was $92 \%$ for low risk patients, $87 \%$ for intermediate risk patients, and $67 \%$ for high risk patients $(p<0.001)$. Four-year RFS was $83 \%$ for low-risk patients, $77 \%$ for intermediate risk patients, and $56 \%$ for high risk patients $(p<0.001)$. The group of patients taking statins had more favorable pretreatment characteristics. A total of $189(27 \%)$ received statin therapy during or after radiation therapy. Statin users had significantly better FFBF $(p<0.001)$, RFS $(p<0.001)$, and freedom from androgen deprivation therapy (98\% vs. $93 \%$ at 4 years; $p=0.0011)$. Statin use was associated with improved FFBF in low-risk (95\% vs. 91\%; $p=0.401)$, intermediate-risk (94\% vs. 84\%; $p=0.0331)$, and high risk groups $(85 \%$ vs. $61 \% ; p=0.0034)$. There was no difference in overall survival (94\% vs. 90\%; $p=0.1235)$, cause-specific survival (99\% vs. $97 \% ; p=0.1535)$, and freedom from distant metastases $(98 \%$ vs. $96 \% ; p=0.2484)$ between the two groups. Fine and Gray's testing indicated a favourable impact of statin use on biochemical failure $(p<0.001)$. In a multivariable analysis model statin use remained significantly associated with improved FFBF $(p=0.03)$ and RFS $(p=0.007)$ (36). Hypothetically, improved FFBF and RFS could positively impact the therapeutic window and therapeutic efficacy of radiotherapy in this patient group.

The 5- and 8- year prostate cancer recurrence free survival (PRFS) for those taking a statin medication were $89 \%(95 \%$ $\mathrm{CI}=85 \%-92 \%)$ and $80 \%(95 \% \mathrm{CI}=72 \%-86 \%)$, compared with $83 \%(95 \% \mathrm{CI}=81 \%-85 \%)$ and $74 \%(95 \% \mathrm{CI}=71 \%-$ $77 \%$ ) for those patients who were not taking statin medication ( $p=0.002$ by $\log$ rank testing). For low and intermediate-risk patients, there was no significant difference in PRFS observed among patients who were taking a statin compared with those who were not $(p=0.91$ and $p=0.43$, respectively). Yet for high-risk patients, a statistically significant PRFS benefit was observed for patients receiving statin therapy with or without adjusting for other clinical/treatment factors $(p=0.02$; adjusted hazard ratio [HR] $0.52 ; 95 \% \mathrm{CI}=0.30-0.91)$. The 5- and 8- year PRFS rates for high-risk patients in the statin group were $80.9 \%$ and $74.5 \%$ compared with $68.1 \%$ and $57.5 \%$, respectively (37).

During the follow up period, 133 patients experienced distant disease recurrence. The overall DMFS rates at 5 and 8 years were $96 \%(95 \% \mathrm{CI}=93 \%-97 \%)$ and $89 \%(95 \%$ $\mathrm{CI}=83 \%-93 \%)$ in the statin group, and $94 \%(95 \% \mathrm{CI}=92 \%-$ $95 \%)$ and $90 \%(95 \% \mathrm{CI}=88 \%-92 \%)$ in the non-statin group ( $p=0.51$ by $\log$ rank test). There were no significant associations between statin or no statin use and DMFS when analysed according to low- $(p=0.97 ; \mathrm{HR}=0.96 ; 95 \%$ $\mathrm{CI}=0.09-9.92)$, intermediate- $\quad(p=0.33 ; \mathrm{HR}=1.44 ; 95 \%$ $\mathrm{CI}=0.69-3.01)$, and high-risk group $(p=0.8 ; \mathrm{HR}=0.92 ; 95 \%$ $\mathrm{CI}=0.51-1.69)$. In the high risk group, 91 patients developed distant disease recurrence, with 79 of 412 patients (19\%) in the no statin group and 12 of the 77 patients (16\%) in the statin group. The 5- and 8-year DMFS rates for statin group vs. no-statin group were $88.4 \%$ vs. $85.2 \%$ and $71.7 \%$ vs. $77.8 \%$, respectively. Improved PRFS has been associated with improved DMFS in several prior reports $(38,39)$. A reduction in metastatic spread has the potential to improve patient quality of life, and consequently, the therapeutic window in radiation therapy. This is in addition to the likely impact of statins use on the risk of radiation-induced side effects, such as erectile dysfunction (40) and acute rectal toxicity (41).

The risk of advanced prostate cancer was decreased among statin users (odds ratio [OR] 0.75, 95\% CI=0.62-0.91) (16, $17,34)$. Current statin use was inversely associated with risk of advanced disease after adjustments for age $(R R=0.48,95 \%$ $\mathrm{CI}=0.29$ to 0.81 ) and after additionally adjustments for prostate cancer risk factors $(\mathrm{RR}=0.51,95 \% \mathrm{CI}=0.30$ to 0.86$)$. The age standardized incident rates of advanced prostate cancer were 38 and 98 per 100,000 person-years among 
current statin users and nonusers, respectively. The inverse association for current use of statins was even stronger for risk of metastatic and fatal prostate cancer combined ( $\mathrm{RR}=0.39,95 \% \mathrm{CI}=0.11$ to 0.85 ).

Haukka et al. detected a linear decreasing trend relating exposure to statins with prostate cancer in 5871 patient cases (42). Sun et al. suggested that statin users were at a decreased risk of mortality when directly compared to nonstatin users (43) (Figure 1).

However, the findings of the Shannon et al. and Graaf et al. studies $(14,15)$ could not be replicated and a reduction in overall prostate cancer risk was not seen in four large, prospectively conducted trials $(16-18,34)$. In three of these four studies, an inverse relationship with advanced prostate cancer was noted for either current or prior statin use, however an overall, decreased prostate cancer risk was not seen. It also remains unclear as to why a $17 \%$ improvement in PRFS did not translate into a statistically significant improvement with DMFS, although there were fewer distant events in the statin group. Perhaps additional follow-up is needed to discern a DMFS benefit because the number of events in the high-risk group overall was small $(n=91)$.

Overall there was no association between statin use and recurrence after prostate cancer diagnosis $(\mathrm{HR}=0.90,95 \%$ $\mathrm{CI}=0.74-1.08$ ). Among men who underwent radiation therapy as the primary treatment, statin users had a statistically significant lower risk of recurrence compared with non-users ( $\mathrm{HR}=0.68 ; 95 \% \mathrm{CI}=0.49-0.93)$ (44). There was also no impact of statin use on overall survival ( $p=0.62$ by log-rank test). To determine whether an association existed between statin use and prostate cancer-related deaths $(\mathrm{m}=53)$ and nonprostate cancer-related deaths $(n=173)$, a univariate competing risk analysis was performed. There was no significant improvement in cause specific survival $(p=0.009)$ or non-prostate cancer-related deaths $(p=0.68)$ for patients taking statin medication before or during radiation therapy compared with those who did not take these medications. There was no significant associations between statin use and prostate cancer-related death when analysed according to low- $(p=0.55)$, intermediate- $(p=1.00)$, and high-risk group $(p=0.28)$. On univariate analysis increasing age $(p=0.0001)$, Gleason score (7vs. $\leq 6, p=0.03)$, and androgen-deprivation therapy use $(p=0.04)$ were significant risk factors associated with non-prostate cancer-related deaths (37).

The Park et al. meta-analysis suggested that statin use did not affect recurrence-free survival based on six randomised control trials (44). Statin use does not have an impact on prostate cancer specific survival (PCSS) on multivariate analysis (45). Large population-based studies also suggest a lack of evidence showing that statins have the properties to reduce the overall risk of developing prostate cancer $(16,34$, 46). Furthermore several large studies were reviewed in the Soto et al. paper, who reported that these studies reported

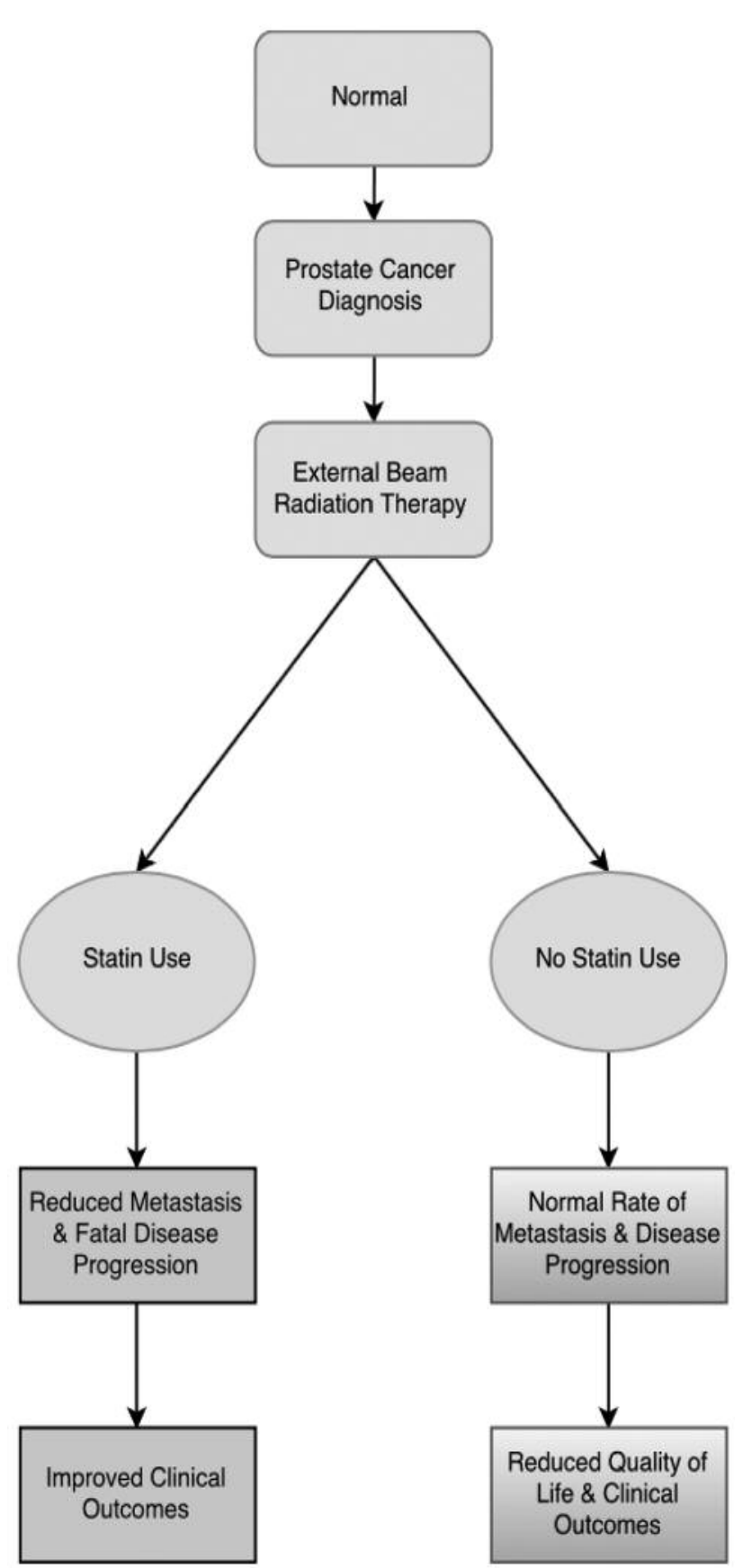

Figure 1. Clinical potential of statin prescription to radiotherapy prostate cancer patients. Once a patient is diagnosed with prostate cancer and external-beam radiation is the chosen as treatment modality, the use of statins either before, during, or after treatment has been shown to reduce the risk of metastatic or fatal disease and improve clinical outcomes such as freedom from biochemical failure (FFBF), relapse-free survival (RFS), prostate-specific antigen relapse-free survival (PRFS) and distant metastatic free survival (DMFS) in patients. The hypothesis that statin use can improve the therapeutic window may be inferred from this data, via the antitumour and radiosensitising properties of statins, as well as their ability to improve clinical outcomes. Flow Chart: adapted from Sun et al. (43). 
largely inconclusive or negative results when correlating statin use and prostate cancer (35).

Radiobiological properties of Statins. Statin therapy for the treatment of hypercholesterolaemia and cardiovascular risk reduction has been in clinical use for decades. More recently, alternative consequences of $\mathrm{HMG}-\mathrm{CoA}$ reductase inhibition have been established. In vitro experimental data suggest that statins are potent inducers of late $\mathrm{G}_{1}$ arrest and apoptosis in prostate cancer cell lines (47-50) (Table II). Although the exact mechanisms of this action have yet to be elucidated, it appears that inhibition of cdk2, E2F1, p21, and/or p27 might have a role $(47,49)$. Cells located in the late $G_{1}$ and $G_{2}-M$ cell cycle phases are more sensitive to radiation-induced cell death, suggesting a potential mechanism of radiosensitisation induced by statins. It is thought that statins induce cell-cycle arrest in prostate cancer cells by reducing cell proliferation and arresting these cells in the $G_{1}$ phase of the cell cycle (51-53).

Additionally, potent anti-proliferative activity has been identified in hormone-independent prostate cancer cell lines (48). Lovastatin-induced apoptosis in colon cell lines revealed decreased expression of the anti-apoptotic protein Bcl-2 and increased expression of the pro-apoptotic protein Bax (50). Statins affect the lipid-raft in plasma membrane which is responsible for signal transduction of key events such as cell growth, survival, and migration (54). Furthermore, statins may inhibit capillary tube formation in endothelial cells in vitro and in vivo and can trigger tumour cells to undergo apoptosis in vitro and supress tumour growth in vivo (55-57). These studies suggest that statins can induce apoptosis and cell growth arrest in prostate cancer cell lines by inactivating RhoA and decreasing c-Jun expression. Finally, depletion of geryanylgeranylated proteins has also been reported as a mechanism through which statin-induced tumor cell apoptosis is mediated (58). Therefore, multiple mechanisms that inhibit tumor cell growth seem to be implicated in the antineoplastic properties of these medications.

Statins exert anti-metastatic effects that may impact cancer risk or progression rates (16). A meta-analysis of 6 randomised control trials and 13 observational studies revealed a statistically significant inverse relationship between statin use and advanced disease, but not overall risk of developing prostate cancer (28). Among statin users, there has been observed a decreased risk in stage II prostate cancer (59). There was a trend towards a risk reduction for metastatic and fatal disease $(16,60,61)$. Low serum cholesterol levels were associated with a reduced risk of developing Gleason score 8-10 prostate cancer (60). Similarly, low plasma cholesterol levels were associated with a low risk of advanced disease (61). Furthermore, the risk of advanced disease may depend on the duration of statin treatment (16). For palliative patients the ratio of high density lipoprotein to total cholesterol decreased daily after radiotherapy, highlighting the likely importance of lipid profile monitoring (62).

Inhibition of HMG-CoA reductase may modulate angiogenesis, in addition to cell-cycle blockade (63-65). The initial step in vascular endothelial growth factor stimulation relies on Rho-dependent pathway that, when blocked by HMG-CoA reductase inhibitors, may interfere with proangiogenic stimuli. Statins have been shown to increase production of nitric oxide through upregulation of endothelial nitric oxide synthetase leading to vasodilation, which is pivotal for the beneficial effects of statins on atherosclerosis prevention (65). This vasodilation may reduce the hypoxic conditions in tumors and thereby improve the efficacy of radiotherapy. Finally, treatment of PC-3 prostate cancer cells with atorvastatin increased the life span of radiation-induced reactive oxygen species and ultimately reduced clonogenic survival (66).

Given the well-established safety and low toxicity of statin use, as well as evidence for potentiation of radiotherapy, there is great interest in a potential benefit of these agents in radiation oncology. There is evidence showing that cells must be proliferating in order to be sensitive to statininduced apoptosis. However, in vitro experiments have indicated that proliferating prostate carcinoma cells are not sensitive to statin-induced apoptosis (57).

Prospective data suggests that statins increase cancer risk in certain segments of the population (67). This phenomenon may be attributed to the reported potential impact of statins on $\mathrm{T}$ cells production. In healthy individuals, statins treatment was associated with the induction of transcription factor forkhead box P3 and a subsequent increase in the number of $\mathrm{T}$ cells (68). $\mathrm{T}$ cells increases have been linked to impaired innate and adaptive immune responses $(69,70)$. In cancer patients, the number of regulatory $\mathrm{T}$ cells in solid tumors is inversely correlated to survival (71). Therefore, it may be speculated that statins-induced $\mathrm{T}$ cell number increase participates in the observed increased risk of prostate cancer in middle-aged long-term statins users (72).

\section{Conclusion}

Statins represent a promising class of agents, which could inhibit the carcinogenic process and improve the therapeutic window of radiotherapy in prostate cancer patients, owing to their antitumor and radiosensitising properties, and their potential to improve clinical outcomes. The use of statins is increasing, and there is a need to pinpoint the mechanisms that underlie their putative anticancer effects. Such evidence would be key in providing rationale for prospective clinical trials of these drugs in a prostate cancer setting. This will 
Table II. Summary table of studies investigating the radiobiological properties of statins in prostate cancer.

\begin{tabular}{lc}
\hline Author & Title \\
\hline Ukomadu et al. (47) & $\begin{array}{c}\text { Inhibition of cdk2 activating } \\
\text { phosphorylation by mevastatin. } \\
\text { Borner } \text { et al. (48) }\end{array}$ \\
$\begin{array}{c}\text { Drug-induced apoptosis is not necessarily } \\
\text { dependent on macromolecular synthesis or } \\
\text { proliferation in the p53-negative } \\
\text { human prostate cancer cell line PC-3. }\end{array}$ \\
Park et al. (49) & $\begin{array}{c}\text { Lovastatin-induced E2F-1 modulation and } \\
\text { its effect on prostate cancer cell death. }\end{array}$ \\
Hoque et al. $(51)$ & $\begin{array}{c}\text { Statin induces apoptosis and cell growth } \\
\text { arrest in prostate cancer cells. }\end{array}$
\end{tabular}

Demierre et al. (54)

Moyad et al. (55)

Moyad et al. (56)

Wong et al. (57)

Platz et al. (16)

Friedman et al. (59)

Platz et al. (61)

Platz et al. (60)

Bonovas et al. (28)

Wolny-Rokicka

et al. (62)

Yu et al. (66)
Statins and cancer prevention.

Why a statin and/or another proven heart healthy agent should be utilized in the next major cancer chemoprevention trial: part I.

Why a statin and/or another proven heart healthy agent should be utilized in the next major cancer chemoprevention trial: part II.

HMG-CoA reductase inhibitors and the malignant cell: the statin family of drugs as triggers of tumor-specific apoptosis.

Statin drugs and risk of advanced prostate cancer. Screening statins for possible carcinogenic risk: up to 9 years of follow-up of 361,859 recipients. Association between plasma cholesterol and prostate cancer in the PSA era.

Men with low serum cholesterol have a lower risk of high-grade prostate cancer in the placebo arm of the prostate cancer prevention trial.

Statin use and the risk of prostate cancer: A metaanalysis of 6 randomized clinical trials and 13 observational studies.

The Comparison and Estimation of the Prognostic Value of Lipid Profiles in Patients With Prostate Cancer Depends on Cancer Stage Advancement Atorvastatin prolongs the lifespan of radiation-induced reactive oxygen species in PC-3 prostate cancer cells to enhance the cell killing effect
Findings

In vitro experimental data suggest that statins are potent inducers of late G1 arrest and apoptosis in the PC-3 prostate cancer cell line. These data indicate that macromolecular synthesis, active cell cycling, and p53 expression are not required for apoptosis to proceed in PC-3 human prostate cancer cells.

Findings imply that E2F-1 is the target of an HMG-CoA inhibitor and critical cell death mediator in prostate cancer cells. Data showed that the antitumor activity of statins is due to induction of apoptosis and cell growth arrest. The underlying molecular mechanism of statin action is mediated through inactivation of RhoA, which in turn induces caspase enzymatic activity and/or G1 cell cycle.

Future studies should focus on examining statins and other apoptosis-inducing drugs (e.g., cyclooxygenase-2

inhibitors or curcumin) together to assess their efficacy in prevention of prostate cancer.

Statins affect the lipid-raft in the plasma membrane, which is responsible for signal transduction of key events such as cell growth, survival, and migration.

In this manuscript, the authors demonstrate the need to test the chemopreventive properties of statins. The authors argue that these drugs can address the rising incidence of cardiovascular diseases and cancer.

In this follow-up manuscript, the authors argue the need to conduct statin chemopreventive trials within the context of cancer treatment. The authors emphasize the clinical potential of statins to reduce cancer risk, decrease mortality due to cardiovascular disease in cancer patients and enhance the therapeutic efficacy of current treatment modalities.

Statins can inhibit capillary tube formation of endothelial cells in vitro and in vivo and have the ability to trigger different tumor cells to undergo apoptosis in vitro and suppress tumor growth in vivo.

Statins have anti-metastatic properties upon prostate cancer.

Overall this study provided no strong evidence of either causation or prevention of cancer by statins.

Found that statin users had a lower risk of advanced and possibly high-grade prostate cancer compared with nonusers.

The association for advanced disease appeared inverse.

Associations remained after excluding cholesterol-lowering drug users. These results coupled with prior statin findings suggest that mechanistic studies on cholesterol metabolism should be pursued to understand a possible target for preventing poorly differentiated prostate cancers. These prospective results support that men with low cholesterol have a reduced risk of high-grade prostate cancer.

These and other contemporary data that suggest that cholesterol metabolism should be investigated further in the etiology of prostate cancer.

Further research is required to investigate whether the particular association of statin use with lower risk of advanced prostate cancer is indeed causal.

This study demonstrates the importance to monitor the lipid profile of prostate cancer patients throughout treatment.

Atorvastatin decreased clonogenic survival following radiation exposure. The treatment induced a decrease in the level of NADPH oxidases

(NOXs) and superoxide dismutase (SOD) activity thereby prolonging the lifespan of radiation- induced reactive oxygen species.

HMG-CoA, 3-Hydroxy-3-methylglutaryl-coenzyme; PSA, prostate specific antigen; NOXs, NADPH oxidases; SOD, superoxide dismutase. 
further elucidate the beneficial effects of statin administration on the clinical outcome of prostate cancer patients treated with radiotherapy.

\section{References}

1 Cooperberg MR, Broering JM, Kantoff PW and Carroll PR: Contemporary trends in low risk prostate cancer: Risk assessment and treatment. J Urol 178(3 Pt 2): S14-19, 2007.

2 Cooperberg MR, Broering JM, Litwin MS, Lubeck DP, Mehta SS, Henning JM and Carroll PR: The contemporary management of prostate cancer in the united states: Lessons from the cancer of the prostate strategic urologic research endeavor (capsure), a national disease registry. J Urol 171(4): 1393-1401, 2004.

3 Kupelian PA, Potters L, Khuntia D, Ciezki JP, Reddy CA, Reuther AM, Carlson TP and Klein EA: Radical prostatectomy, external beam radiotherapy $<72$ gy, external beam radiotherapy $>$ or $=72 \mathrm{gy}$, permanent seed implantation, or combined seeds/external beam radiotherapy for stage $\mathrm{t} 1$ - $\mathrm{t} 2$ prostate cancer. Int J Radiat Oncol Biol Phys 58(1): 25-33, 2004.

4 Burkhardt JH, Litwin MS, Rose CM, Correa RJ, Sunshine JH, Hogan $\mathrm{C}$ and Hayman JA: Comparing the costs of radiation therapy and radical prostatectomy for the initial treatment of early-stage prostate cancer. J Clin Oncol 20(12): 2869-2875, 2002.

5 Sanda MG, Dunn RL, Michalski J, Sandler HM, Northouse L, Hembroff L, Lin X, Greenfield TK, Litwin MS, Saigal CS, Mahadevan A, Klein E, Kibel A, Pisters LL, Kuban D, Kaplan I, Wood D, Ciezki J, Shah N and Wei JT: Quality of life and satisfaction with outcome among prostate-cancer survivors. N Engl J Med 358(12): 1250-1261, 2008.

6 D'Amico AV, Cote K, Loffredo M, Renshaw AA and Schultz D: Determinants of prostate cancer-specific survival after radiation therapy for patients with clinically localized prostate cancer. J Clin Oncol 20(23): 4567-4573, 2002.

7 Karakiewicz PI and Hutterer GC: Predictive models and prostate cancer. Nat Clin Pract Urol 5(2): 82-92, 2008.

8 Klotz L: Active surveillance for prostate cancer: For whom? J Clin Oncol 23(32): 8165-8169, 2005.

9 Andriole GL, Crawford ED, Grubb RL, 3rd, Buys SS, Chia D, Church TR, Fouad MN, Gelmann EP, Kvale PA, Reding DJ, Weissfeld JL, Yokochi LA, O'Brien B, Clapp JD, Rathmell JM, Riley TL, Hayes RB, Kramer BS, Izmirlian G, Miller AB, Pinsky PF, Prorok PC, Gohagan JK and Berg CD: Mortality results from a randomized prostate-cancer screening trial. $\mathrm{N}$ Engl J Med 360(13): 1310-1319, 2009.

10 Schroder FH, Hugosson J, Roobol MJ, Tammela TL, Ciatto S, Nelen V, Kwiatkowski M, Lujan M, Lilja H, Zappa M, Denis LJ, Recker F, Berenguer A, Maattanen L, Bangma CH, Aus G, Villers A, Rebillard X, van der Kwast T, Blijenberg BG, Moss SM, de Koning HJ and Auvinen A: Screening and prostatecancer mortality in a randomized european study. N Engl J Med 360(13): 1320-1328, 2009.

11 Gomella LG, Johannes J and Trabulsi EJ: Current prostate cancer treatments: Effect on quality of life. Urology 73(5 Suppl): S28-35, 2009.

12 Svatek RS, Lee JJ, Roehrborn CG, Lippman SM and Lotan Y: Cost-effectiveness of prostate cancer chemoprevention: A quality of life-years analysis. Cancer 112(5): 1058-1065, 2008.
13 Mann D, Reynolds K, Smith D and Muntner P: Trends in statin use and low-density lipoprotein cholesterol levels among us adults: Impact of the 2001 national cholesterol education program guidelines. Ann Pharmacother 42(9): 1208-1215, 2008.

14 Shannon J, Tewoderos S, Garzotto M, Beer TM, Derenick R, Palma A and Farris PE: Statins and prostate cancer risk: A casecontrol study. Am J Epidemiol 162(4): 318-325, 2005.

15 Graaf MR, Beiderbeck AB, Egberts AC, Richel DJ and Guchelaar HJ: The risk of cancer in users of statins. J Clin Oncol 22(12): 2388-2394, 2004.

16 Platz EA, Leitzmann MF, Visvanathan K, Rimm EB, Stampfer MJ, Willett WC and Giovannucci E: Statin drugs and risk of advanced prostate cancer. J Natl Cancer Inst 98(24): 1819-1825, 2006.

17 Jacobs EJ, Rodriguez C, Bain EB, Wang Y, Thun MJ and Calle EE: Cholesterol-lowering drugs and advanced prostate cancer incidence in a large u.S. Cohort. Cancer Epidemiol Biomarkers Prev 16(11): 2213-2217, 2007.

18 Flick ED, Habel LA, Chan KA, Van Den Eeden SK, Quinn VP, Haque R, Orav EJ, Seeger JD, Sadler MC, Quesenberry CP Jr., Sternfeld B, Jacobsen SJ, Whitmer RA and Caan BJ: Statin use and risk of prostate cancer in the california men's health study cohort. Cancer Epidemiol Biomarkers Prev 16(11): 2218-2225, 2007.

19 Papadopoulos G, Delakas D, Nakopoulou L and Kassimatis T: Statins and prostate cancer: Molecular and clinical aspects. Eur J Cancer 47(6): 819-830, 2011.

20 Graaf MR, Richel DJ, van Noorden CJ and Guchelaar HJ: Effects of statins and farnesyltransferase inhibitors on the development and progression of cancer. Cancer Treat Rev 30(7): 609-641, 2004.

21 Hamilton RJ and Freedland SJ: Review of recent evidence in support of a role for statins in the prevention of prostate cancer. Curr Opin Urol 18(3): 333-339, 2008.

22 Thurnher M, Nussbaumer O and Gruenbacher G: Novel aspects of mevalonate pathway inhibitors as antitumor agents. Clin Cancer Res 18(13): 3524-3531, 2012.

23 Pon D, Abe A and Gupta EK: A review of statin use and prostate cancer. Curr Atheroscler Rep 17(2): 474, 2015

24 Chan KK, Oza AM and Siu LL: The statins as anticancer agents. Clin Cancer Res 9(1): 10-19, 2003.

25 Nielsen SF, Nordestgaard BG and Bojesen SE: Statin use and reduced cancer-related mortality. N Engl J Med 367(19): 17921802, 2012.

26 Bonkhoff $\mathrm{H}$ : Factors implicated in radiation therapy failure and radiosensitization of prostate cancer. Prostate Cancer 2012: 593241, 2012.

27 Montgomery RB, Mostaghel EA, Vessella R, Hess DL, Kalhorn TF, Higano CS, True LD and Nelson PS: Maintenance of intratumoral androgens in metastatic prostate cancer: A mechanism for castration-resistant tumor growth. Cancer Res 68(11): 4447-4454, 2008.

28 Bonovas S, Filioussi K and Sitaras NM: Statin use and the risk of prostate cancer: A metaanalysis of 6 randomized clinical trials and 13 observational studies. Int J Cancer 123(4): 899-904, 2008.

29 Browning DR and Martin RM: Statins and risk of cancer: A systematic review and metaanalysis. Int J Cancer 120(4): 833843, 2007.

30 Dale KM, Coleman CI, Henyan NN, Kluger J and White CM: Statins and cancer risk: A meta-analysis. JAMA 295(1): 74-80, 2006. 
31 Roberts CG, Guallar E and Rodriguez A: Efficacy and safety of statin monotherapy in older adults: A meta-analysis. J Gerontol A Biol Sci Med Sci 62(8): 879-887, 2007.

32 Stein EA, Corsini A, Gimpelewicz CR, Bortolini M and Gil M: Fluvastatin treatment is not associated with an increased incidence of cancer. Int J Clin Pract 60(9): 1028-1034, 2006.

33 Taylor ML, Wells BJ and Smolak MJ: Statins and cancer: A meta-analysis of case-control studies. Eur J Cancer Prev 17(3): 259-268, 2008.

34 Murtola TJ, Tammela TL, Lahtela J and Auvinen A: Cholesterollowering drugs and prostate cancer risk: A population-based case-control study. Cancer Epidemiol Biomarkers Prev 16(11): 2226-2232, 2007.

35 Soto DE, Daignault S, Sandler HM and Ray ME: No effect of statins on biochemical outcomes after radiotherapy for localized prostate cancer. Urology 73(1): 158-162, 2009.

36 Gutt R, Tonlaar N, Kunnavakkam R, Karrison T, Weichselbaum RR and Liauw SL: Statin use and risk of prostate cancer recurrence in men treated with radiation therapy. J Clin Oncol 28(16): 2653-2659, 2010.

37 Kollmeier MA, Katz MS, Mak K, Yamada Y, Feder DJ, Zhang Z, Jia X, Shi W and Zelefsky MJ: Improved biochemical outcomes with statin use in patients with high-risk localized prostate cancer treated with radiotherapy. Int J Radiat Oncol Biol Phys 79(3): 713-718, 2011.

38 Zelefsky MJ, Chan H, Hunt M, Yamada Y, Shippy AM and Amols H: Long-term outcome of high dose intensity modulated radiation therapy for patients with clinically localized prostate cancer. J Urol 176(4): 1415-1419, 2006.

39 Kuban DA, Tucker SL, Dong L, Starkschall G, Huang EH, Cheung MR, Lee AK and Pollack A: Long-term results of the m. D. Anderson randomized dose-escalation trial for prostate cancer. Int J Radiat Oncol Biol Phys 70(1): 67-74, 2008

40 Anscher MS, Chang MG, Moghanaki D, Rosu M, Mikkelsen RB, Holdford D, Skinner V, Grob BM, Sanyal A, Wang A and Mukhopadhyay ND: Lovastatin may reduce the risk of erectile dysfunction following radiation therapy for prostate cancer. Acta Oncol 55(12): 1500-1502, 2016.

41 Palumbo I, Matrone F, Montesi G, Bellavita R, Lupattelli M, Saldi S, Frattegiani A, Arena E, Mariucci C, Falcinelli L, Bini $\mathrm{V}$ and Aristei C: Statins protect against acute rt-related rectal toxicity in patients with prostate cancer: An observational prospective study. Anticancer Res 37(3): 1453-1457, 2017.

42 Haukka J, Sankila R, Klaukka T, Lonnqvist J, Niskanen L, Tanskanen A, Wahlbeck K and Tiihonen J: Incidence of cancer and statin usage - record linkage study. Int J Cancer 126(1): 279-284, 2010.

43 Sun LM, Lin MC, Lin CL, Chang SN, Liang JA, Lin IC and Kao $\mathrm{CH}$ : Statin use reduces prostate cancer all-cause mortality: A nationwide population-based cohort study. Medicine (Baltimore) 94(39): e1644, 2015.

44 Park HS, Schoenfeld JD, Mailhot RB, Shive M, Hartman RI, Ogembo $R$ and Mucci LA: Statins and prostate cancer recurrence following radical prostatectomy or radiotherapy: A systematic review and meta-analysis. Ann Oncol 24(6): $1427-$ 1434, 2013

45 Caon J, Paquette M, Hamm J and Pickles T: Does statin or asa affect survival when prostate cancer is treated with external beam radiation therapy? Prostate Cancer 2014: 184297, 2014.
46 Boudreau DM, Yu O, Buist DS and Miglioretti DL: Statin use and prostate cancer risk in a large population-based setting. Cancer Causes Control 19(7): 767-774, 2008.

47 Ukomadu C and Dutta A: Inhibition of cdk2 activating phosphorylation by mevastatin. J Biol Chem 278(7): 4840-4846, 2003.

48 Borner MM, Myers CE, Sartor O, Sei Y, Toko T, Trepel JB and Schneider E: Drug-induced apoptosis is not necessarily dependent on macromolecular synthesis or proliferation in the p53-negative human prostate cancer cell line pc-3. Cancer Res 55(10): 2122-2128, 1995.

49 Park C, Lee I and Kang WK: Lovastatin-induced e2f-1 modulation and its effect on prostate cancer cell death. Carcinogenesis 22(10): 1727-1731, 2001.

50 Agarwal B, Bhendwal S, Halmos B, Moss SF, Ramey WG and Holt PR: Lovastatin augments apoptosis induced by chemotherapeutic agents in colon cancer cells. Clin Cancer Res 5(8): 2223-2229, 1999.

51 Hoque A, Chen $\mathrm{H}$ and $\mathrm{Xu} \mathrm{XC}$ : Statin induces apoptosis and cell growth arrest in prostate cancer cells. Cancer Epidemiol Biomarkers Prev 17(1): 88-94, 2008.

52 Singh H, Canto EI, Shariat SF, Kadmon D, Miles BJ, Wheeler TM and Slawin KM: Improved detection of clinically significant, curable prostate cancer with systematic 12-core biopsy. J Urol 171(3): 1089-1092, 2004.

53 Singh PP and Singh S: Statins - the holy grail for cancer? Ann Transl Med 1(1): 1, 2013.

54 Demierre MF, Higgins PD, Gruber SB, Hawk E and Lippman SM: Statins and cancer prevention. Nat Rev Cancer 5(12): 930942, 2005.

55 Moyad MA: Why a statin and/or another proven heart healthy agent should be utilized in the next major cancer chemoprevention trial: Part i. Urol Oncol 22(6): 466-471, 2004.

56 Moyad MA: Why a statin and/or another proven heart healthy agent should be utilized in the next major cancer chemoprevention trial: Part ii. Urol Oncol 22(6): 472-477, 2004.

57 Wong WW, Dimitroulakos J, Minden MD and Penn LZ: Hmgcoa reductase inhibitors and the malignant cell: The statin family of drugs as triggers of tumor-specific apoptosis. Leukemia 16(4): 508-519, 2002.

58 Chan KKW, Oza AM and Siu LL: The statins as anticancer agents. Clinical Cancer Research 9(1): 10, 2003.

59 Friedman GD, Flick ED, Udaltsova N, Chan J, Quesenberry CP, Jr. and Habel LA: Screening statins for possible carcinogenic risk: Up to 9 years of follow-up of 361,859 recipients. Pharmacoepidemiol Drug Saf 17(1): 27-36, 2008.

60 Platz EA, Till C, Goodman PJ, Parnes HL, Figg WD, Albanes D, Neuhouser ML, Klein EA, Thompson IM Jr. and Kristal AR: Men with low serum cholesterol have a lower risk of high-grade prostate cancer in the placebo arm of the prostate cancer prevention trial. Cancer Epidemiol Biomarkers Prev 18(11): 2807-2813, 2009.

61 Platz EA, Clinton SK and Giovannucci E: Association between plasma cholesterol and prostate cancer in the psa era. Int $\mathrm{J}$ Cancer 123(7): 1693-1698, 2008

62 Wolny-Rokicka EI, Tukiendorf A, Wydmanski J and ZembronLacny A: The comparison and estimation of the prognostic value of lipid profiles in patients with prostate cancer depends on cancer stage advancement. Am J Mens Health: 155798831 $7717382,2017$. 
63 Park HJ, Kong D, Iruela-Arispe L, Begley U, Tang D and Galper JB: 3-hydroxy-3-methylglutaryl coenzyme a reductase inhibitors interfere with angiogenesis by inhibiting the geranylgeranylation of rhoa. Circ Res 91(2): 143-150, 2002.

64 Laufs U, La Fata V, Plutzky J and Liao JK: Upregulation of endothelial nitric oxide synthase by hmg coa reductase inhibitors. Circulation 97(12): 1129-1135, 1998.

65 Hernandez-Perera O, Perez-Sala D, Navarro-Antolin J, SanchezPascuala R, Hernandez G, Diaz C and Lamas S: Effects of the 3-hydroxy-3-methylglutaryl-coa reductase inhibitors, atorvastatin and simvastatin, on the expression of endothelin-1 and endothelial nitric oxide synthase in vascular endothelial cells. J Clin Invest 101(12): 2711-2719, 1998.

$66 \mathrm{Yu} \mathrm{H}$, Sun SQ, Gu XB, Wang W and Gao XS: Atorvastatin prolongs the lifespan of radiationinduced reactive oxygen species in pc-3 prostate cancer cells to enhance the cell killing effect. Oncol Rep 37(4): 2049-2056, 2017.

67 Goldstein MR, Mascitelli L and Pezzetta F: Do statins prevent or promote cancer? Current Oncology 15(2): 76-77, 2008.

68 Mausner-Fainberg K, Luboshits G, Mor A, Maysel-Auslender S, Rubinstein A, Keren $\mathrm{G}$ and George J: The effect of hmg-coa reductase inhibitors on naturally occurring cd $4+\mathrm{cd} 25+\mathrm{t}$ cells. Atherosclerosis 197(2): 829-839, 2008.
69 Tiemessen MM, Jagger AL, Evans HG, van Herwijnen MJ, John $S$ and Taams LS: Cd4+cd25+foxp3+ regulatory t cells induce alternative activation of human monocytes/macrophages. Proc Natl Acad Sci USA 104(49): 19446-19451, 2007.

70 Curiel TJ: Tregs and rethinking cancer immunotherapy. J Clin Invest 117(5): 1167-1174, 2007.

71 Yakirevich E and Resnick MB: Regulatory t lymphocytes: Pivotal components of the host antitumor response. J Clin Oncol 25(18): 2506-2508, 2007.

72 Ford I, Murray H, Packard CJ, Shepherd J, Macfarlane PW and Cobbe SM: Long-term follow-up of the west of scotland coronary prevention study. N Engl J Med 357(15): 1477-1486, 2007.
Received July 10, 2017

Revised August 15, 2017

Accepted August 25, 2017 